\title{
Treatment of Metabolic Syndrome in Children
}

\author{
Elena Fornari and Claudio Maffeis* \\ Pediatric Diabetes and Metabolic Disorders Unit, Department of Surgical Sciences, Dentistry, and Pediatrics, and \\ Gynecology, University of Verona, Verona, Italy
}

The Metabolic Syndrome may be tentatively defined as the clustering of several metabolic risk factors in the same individual. A progressively higher number of children and adolescents is affected by this syndrome worldwide, mainly as a consequence of the constant increase of the prevalence of obesity and sedentary habits. As obesity, the chance that the metabolic syndrome traks into adulthood is high. Moreover, the evidence of an association between the duration of the exposition to metabolic risk factors and morbidity and mortality justifies early treatment and prevention of the metabolic syndrome in both children and adolescents. Treatment includes behavioral interventions, adequate nutrition and physical activity, and, if necessary, pharmacological treatments aimed at reducing excessive weight, dyslipidemia, hypertension, and glucose impairments. A multidisciplinary and staged approach to treatment, which includes pediatrician, mental health practitioner, dietician, and nurses, is crucial. Usually, the reduction of fat mass promotes an overall improvement of all the components of the metabolic syndrome. Nevertheless, every single component of the metabolic syndrome should be treated as quickly as possible, by using the best current practice. Drugs may be necessary for treating hypertension, type 2 diabetes mellitus and dyslipidemia. In selected cases of gross obesity resistant to treatment, surgical therapy may be also performed.

Keywords: obesity, treatment, children, adolescents, metabolic syndrome

\section{INTRODUCTION}

Regardless of the many different definitions of the Metabolic Syndrome (MetS) in child and adolescent (1-4), early screening and treating the single components, which contribute to its development, have a pivotal role in reducing cardiometabolic risk (5). There is no uniform agreement in how to treat the individual risk factors other than excessive weight management. However, the set of MetS component risk factors share their pathophysiologic origins and many common treatment approaches grounded in lifestyle modifications (Figure 1) (5). The Bogalusa Heart Study demonstrated that every single risk factor increases the development and severity of atherosclerotic lesions (6). The American Academy of Pediatrics (AAP) underlines the importance to treat each risk factor individually, independently from the definition of MetS, with the ultimate goal of reducing cardiometabolic risk (5). In fact, the concept of CVR has to be considered a continuum and not the sum of the overcoming of cut-off points for the single risk factors (5).

Treatment of MetS includes behavioral interventions and, if necessary, pharmacological treatments aimed at reducing excessive weight, dyslipidemia, hypertension, and glucose impairments (Table 1) $(7,8)$. Once every single risk factor is identified, it should be treated by using the best current practice as quickly as possible. The Princeton Prevalence and Follow-up Studies 


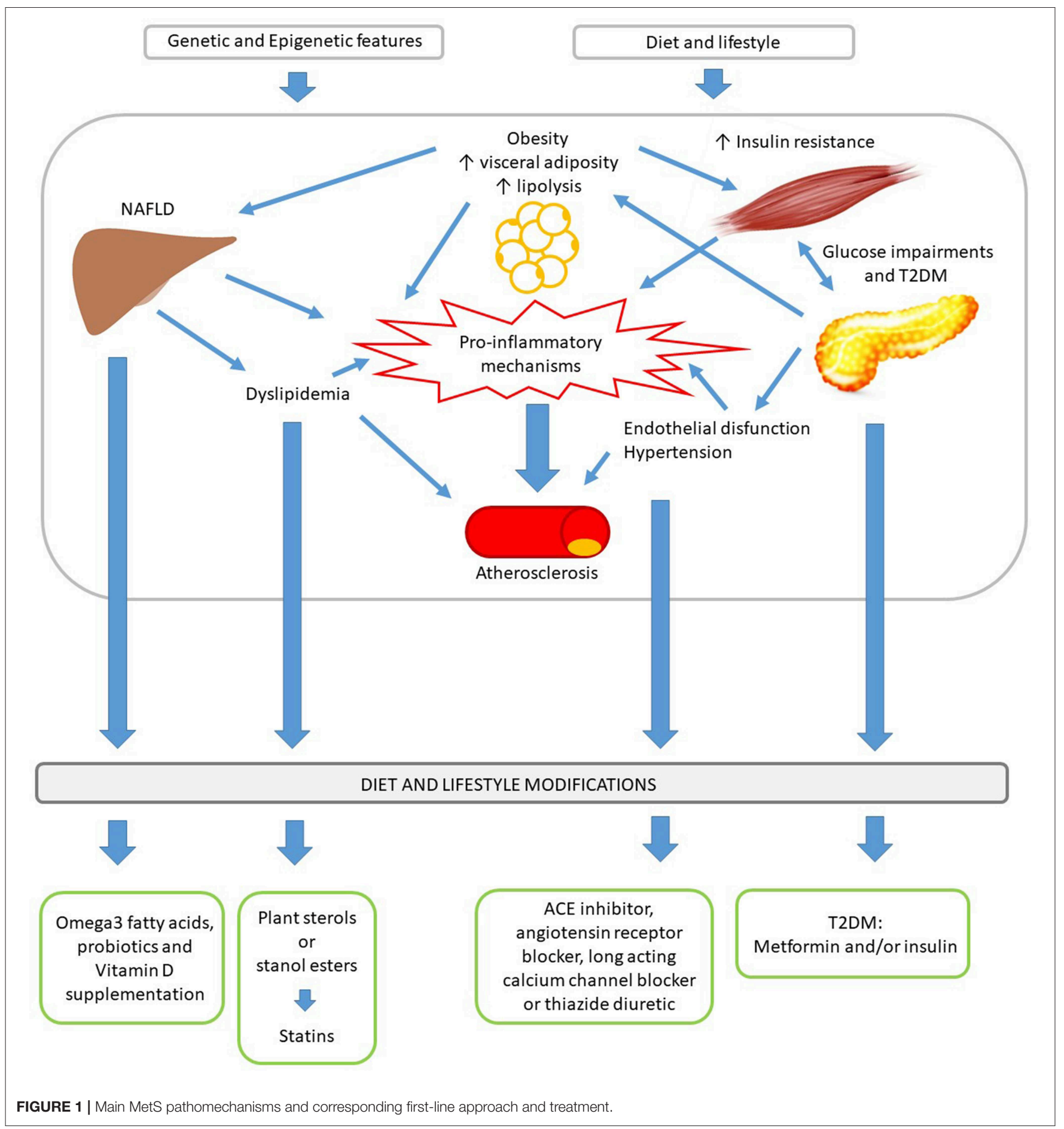

demonstrated that pediatric MetS predicted adults MetS with an OR of 9.4 (9). Considering that the maintenance of the pathologic conditions until adulthood increases the risk, early treatment is essential (5).

There is common agreement that obesity prevention and treatment in children and adolescents is "the first-line approach" to reduce the cardiovascular risk $(\mathrm{CVR})(8,10)$. In fact, prevalence of metabolic syndrome in childhood is increasing in parallel with the increasing trends in obesity rates (11, 12). In addition, although the pathogenesis of MetS is not completely understood, good evidence suggests that interactions between obesity, insulin resistance and pro-inflammatory state, certainly play a key role in its development and maintenance (13). Treatment of obesity and other MetS 
TABLE 1 | List of MetS components and corresponding first-line approach and treatment.

\begin{tabular}{|c|c|c|}
\hline Mets components & First-line approach & Treatment \\
\hline Obesity & $\begin{array}{l}\text { Lifestyle interventions: } \\
\text { 1. Diet (caloric restriction, specific targets suggested by dietitians) } \\
\text { 2. PA ( } 60 \text { min of moderate/vigorous PA every day, including } \\
\text { vigorous activity } 3 \text { day per week) }\end{array}$ & $\begin{array}{l}\text { 1. PHARMACOLOGIC TREATMENT } \\
\text { Orlistat, when indicated } \\
\text { 2. SURGICALTREATMENT } \\
\text { Bariatric surgery, when indicated }\end{array}$ \\
\hline Hypertension & $\begin{array}{l}\text { Lifestyle interventions: } \\
\text { 1. Diet (reducing sodium, increasing olive oil polyphenols, } \\
\text { increasing intake of fruits, and vegetables) } \\
\text { 2. PA(30-60 min of moderate/vigorous PA at least 3-5 days } \\
\text { per week) }\end{array}$ & $\begin{array}{l}\text { PHARMACOLOGIC TREATMENT } \\
\text { Start with a single medication at the low end of dosing range. } \\
\text { Titrate every } 2-4 \text { weeks. ACE inhibitor, angiotensin receptor } \\
\text { blocker, long acting calcium channel blocker or thiazide } \\
\text { dieuretic are the first choices }\end{array}$ \\
\hline Dyslipidemia & $\begin{array}{l}\text { Lifestyle interventions: } \\
\text { 1. Diet (reducing total fat between } 25 \text { and } 30 \% \text { of daily calories } \\
\text { and cholesterol intake }<300 \mathrm{mg} / \text { day, reducing simple } \\
\text { carbohydrate intake, possible use of plant sterols or stanol } \\
\text { esters) } \\
\text { 2. PA }\end{array}$ & $\begin{array}{l}\text { PHARMACOLOGIC TREATMENT } \\
\text { Statins when indicated }\end{array}$ \\
\hline NAFLD & $\begin{array}{l}\text { 1. Lifestyle interventions and weight loss. } \\
\text { 2. Probiotics and omega3 fatty acids may ameliorate disease } \\
\text { progression. } \\
\text { 3. Vitamin E can improve hepatocellular balloning }\end{array}$ & \\
\hline
\end{tabular}

PA, physical activity; BP, blood pressure; T2DM, type 2 diabetes mellitus; NAFLD, non-alcoholic fatty liver disease.

components share many common elements, so interventions that improve one condition could consequently be useful to ameliorate also the others. For example, weight reduction following non-surgical interventions, including dietary changes, increased physical activity, and behavioral therapy, was found to be associated with improvements in several metabolic parameters such as dyslipidemia and hypertension (14-16). Weight reduction also results in decrease of insulin resistance and low-grade inflammation (17). Combining dietary interventions and physical activity is more effective than either single intervention in reducing BMI (5). In addition, data from a meta-analysis demonstrate that the positive effect of ameliorating unhealthy diets and reducing sedentary behavior in long-term trials was more pronounced when directed toward children compared to adolescents (18). Therefore, early management and treatment are crucial, in particular in pediatric population.

\section{DIETARY INTERVENTION}

The mechanisms that explain the correlation between diet modification and effects on MetS components are not fully clear. Lowering intake of simple sugars may reduce pancreatic stimulus for insulin production (5). Caloric restriction reduce mitochondrial substrate availability (19) whereas increased dietary fiber intake decreases the glycemic load (20). The primary goal in dietary intervention programs should focus on reducing total energy intake (21). It is essential that a dietician with proved experience in growing children's needs supervise the caloric reduction $(20,22)$. Specific targets for dietary habits have also demonstrated efficacy in reducing BMI, i.e., substitution of sugarsweetened beverages with water (23), portion control education, increased intake of fruits and vegetables, reduction of dietary fats, sodium, and processed foods, increased intake of fiber $(8,20,24)$. The AAP Guidelines report the appropriate recommendations about diet and nutrition in the prevention and first-line therapy approach of obesity and other risk factors (8). Specific nutritional interventions for the therapy of each single MetS component will be treated in the respective paragraph of the text. The intervention of an expert multidisciplinary team, which includes dietician, psychologist, and providers with proven experience with pediatric obesity, is much more effective to obtain a modification of eating habits than other approaches $(20,25)$.

\section{PHYSICAL ACTIVITY}

Physical activity is any body movement produced by contraction of skeletal muscle, which results in an increase in energy expenditure above the basal level (8). Strong evidences prove the beneficial metabolic effects of reducing sedentary behavior, i.e., increasing walking and physical activity on the overall health of children and adolescents (8, 26-28). In addition, physical inactivity has been identified as an independent risk factor for coronary heart disease in adults (29). Time spent in moderate to vigorous physical exercise is inversely associated with continuous risk score of MetS (30). Therefore, an increase in physical activity, also independently form a change in weight status, represents an important treatment strategy for childhood MetS and results in improving of metabolic parameters and subclinical measures of atherosclerosis $(8,20)$.

Physical activity increases hepatic mitochondrial substrate metabolism, reducing the availability of substrate for lipogenesis and mitigating insulin resistance $(31,32)$ and causes 
TABLE 2 | Guidelines for preschool-aged children and for school-aged children and adolescents.

Preschool-aged children (3 through 5 years)

School-aged children and adolescents (6 through 17 years)
Preschool-aged children should be physically active throughout the day to enhance growth and development. Adult caregivers should encourage active play that includes a variety of activity types

Provide opportunities and encouragement to participate in physical activities appropriate for age and enjoyable. Children and adolescents should do $60 \mathrm{~min}$ (1 h) or more of moderate-to-vigorous physical activity daily

Aerobic: Most of the 60 min or more per day should be either moderate- or vigorous-intensity aerobic physical activity and should include vigorous-intensity physical activity on at least 3 days a week

Muscle-strengthening: As part of their 60 min or more of daily physical activity, children, and adolescents should include muscle-strengthening physical activity on at least 3 days a week

Bone-strengthening: As part of their $60 \mathrm{~min}$ or more of daily physical activity, children, and adolescents should include bone-strengthening physical activity on at least 3 days a week

Modified by (39).

mitochondrial biogenesis in liver and muscles (32). There is strong evidence that physical exercise promotes a reduction of fasting insulin levels and decreased insulin resistance in children and adolescents (31). It is helpful in improving lipid profile by increasing HDL concentration and decreasing both LDL and triglycerides concentrations (33). In addition, exercise can result in improvement of endothelial function with reduction in both systolic and diastolic blood pressure, independently from the type of training (aerobic, resistance, or combined) (34). It ameliorates body composition and has an abdominal fat reduction effect (34-36). As activity levels increase, proinflammatory cytokines and markers of oxidative stress decrease (31), producing anti-inflammatory effects (37).

Structured physical activity interventions favor decreased daily energy intake in obese adolescents (38). The AAP recommends at least $60 \mathrm{~min}$ of moderate-to-vigorous activity every day for children older than 5 years, including vigorous activity on 3 days per week (8). A more conservative approach for both prevention and treatment of obesity and related risk factors has been suggested by the Endocrine Society. They recommend the reduction of inactivity and a minimum of 20 min of moderate to vigorous physical activity daily, with a goal of $60 \mathrm{~min}$, all in the context of a calorie-controlled diet (20). The most recent American Guidelines on physical activity confirm the AAP and the Endocrine Society recommendations for children and adolescents (Table 2) (39). In severe obese subjects exercises that cause constant weight or repeated impact on the child's legs, feet, and hips should be avoided (22).

\section{OTHER LIFESTYLE MODIFICATIONS AND BEHAVIORAL TREATMENT}

Other than adopting healthy eating habits and increasing physical activity, the primary goal in prevention and treatment of obesity and MetS in pediatric population includes lifestyle modifications, such as limiting video exposition time $(23,40)$ and adopting healthy sleep habits. Disordered sleep length and quality affect appetite and decrease insulin sensitivity (41). The AAP recommends to limit screen time to $<2 \mathrm{~h}$ /day (8). The National Sleep Foundation recommends $8-11 \mathrm{~h}$ of sleep for school age children and adolescents (42). Even independently by the severity of obesity, these additional behavioral modifications reduce the likelihood of developing MetS (20, 24).

Pediatrician should assess patients and families for readiness to change. This information can guide the type and degree of interventions and may help to avoid excess time investing in noneffective interventions (13). Programs involving the whole family in lifestyle modifications have more positive and durable effects compared to those directed at child alone $(8,35)$.

\section{PHARMACOLOGICAL AND SURGICAL TREATMENT OF OBESITY}

Pharmacotherapy of obesity in children is limited. There are poor evidences regarding the safety and efficacy of pharmacological agents aimed to weight reduction in adolescents, especially in the long term (43). When indicated, pharmacological therapies should be prescribed by experienced clinicians, who can offer close monitoring for weight reduction result and potential side effects. In addition, pharmacological option should be considered only after the proved failure of a formal program of lifestyle modification, which should however be continued in parallel with pharmacotherapy (20). Currently, the US Food and Drug Administration (FDA) indicates only Orlistat for weight loss in adolescents over 12 years of age (44). By inhibiting intestinal lipase, it reduces the absorption of triglycerides and cholesterol (45). It has frequent gastrointestinal adverse effects and can affect the absorption of fat-soluble vitamins (46). Pharmacological treatment efficacy is limited. At 6 and 12 months of follow-up, it determines, respectively, an average weight loss of 3 and 5\% $(47,48)$. Weight loss agents, other than Orlistat, are still under investigation for the use in adolescents $(16,49,50)$.

Bariatric surgery can result in significant short-term weight loss in obese adolescents, but it is reserved for the most severely affected subjects, who have already completed or almost completed their growth and have completed pubertal development $(22,51,52)$. Surgical option is recommended only if BMI exceeds $40 \mathrm{~kg} / \mathrm{m}^{2}$ with mild comorbidities or 35 $\mathrm{kg} / \mathrm{m}^{2}$ with severe comorbidities. Severe comorbidities include type 2 diabetes mellitus (T2DM), moderate to severe sleep apnea, severe hepatic fibrosis resulting from non-alcoholic steatohepatitis (NASH), pseudotumor cerebri, or debilitating 
orthopedic problems. Mild comorbidities include dyslipidemia, hypertension, mild sleep apnea, moderate orthopedic problems, $\mathrm{NASH}$, and psychological distress related to obesity $(20,22)$. Bariatric surgery should be considered only after the failure of a formal lifestyle modification program with documented compliance $(20,22)$. Prior to proceed with surgery, family competency should be evaluated, as well as should be excluded potential underlying psychiatric illnesses, substance abuse or eating disorders. The benefits of surgery option must be evaluated in the context of potential surgical complications (53). The research on the safety, efficacy, and long-term outcomes of bariatric surgery in adolescents is limited, but data on adults must be considered as surrogate evidence (54). Serious and short-term complications (i.e., abscess, infections, pulmonary embolism, etc.) can occur in $4.1 \%$ of all patients (53). A recent longitudinal study on a cohort of 161 adolescents reports $1.9 \%$ of mortality in the 5 years after surgery (55). Mild- and longterm complications, which include intestinal obstruction, ulcers and hernia, and metabolic complications (i.e., nephrolithiasis, hypoglycemia and vitamin, or mineral deficiencies) may also be considered but are hardly to monitor because of the high rate of dropout to the follow-up (53). Bariatric surgery in adolescents can result in improvement or resolution of comorbid conditions, such as T2DM, sleep apnea and hypertension, and can lead to good effect on weight loss $(55,56)$. However, further research is required because of the impact of the development of complications and the relatively poor number of trials which determine the long-term efficacy and safety in adolescents $(53,54$, 57). Literature consistently reports that both surgeon and surgical center experience are predictors of safety and a team of specialists capable of long-term medical and psychological follow-up care for the patient is essential $(20,54)$.

\section{TREATMENT OF MetS RISK FACTORS OR COMPONENTS OTHER THAN OBESITY}

Treatment of childhood MetS include disease-specific management of its various components. Cardiovascular morbidity represents the effect of a continuum in the spectrum of the single CVR factors and a youth with multiple borderline risk factors might have equivalent risk of a person with extreme abnormality of a single major risk factor (8). The presence of any combination of multiple risk factors should prompt intensification of therapy (8).

\section{HYPERTENSION}

The overall aims of hypertension (HTN) treatment in pediatric population should include obtaining a blood pressure (BP) level that reduce the risk of target organ damage and reducing the risk of maintaining hypertension and related increasing CVR in adulthood (58). The new Guidelines for High Blood Pressure in children and adolescents, published in 2017, indicate as the goal of non-pharmacological and pharmacological therapy a BP $<90$ th percentile or $<130 / 80 \mathrm{mmHg}$ in adolescents $\geq 13$ years old (58).
Lifestyle intervention are the first-line approach recommended for HTN (58). There is good evidence in adults as in childhood that nutritional interventions, including reduced dietary sodium and increased olive oil polyphenols intake, result in lowering BP levels and cardiovascular mortality (59-61). In addition, higher intake of fruits and vegetables are also associated with lower BP and with lower risk of high BP in young adulthood $(62,63)$. Several studies conducted in children and adolescents support the evidence of the benefit of physical activity on BP (64), also independently from the type of exercise (aerobic training, resistance training or combined training) (34). AAP recommends sessions of 30-60 min of moderate to vigorous physical activity at least 3-5 days per week (58).

When HTN persists despite lifestyle modifications or in case of symptomatic HTN or stage II hypertension without modifiable factors, pharmacologic treatment should be initiated (58). Therapy should be started with a single medication at the low end of dosing range and can be titrated every 2-4 weeks. The patient should be seen every 4-6 weeks until BP has normalized (e.g., <90th percentile), than the frequency of visits can be extended to every 3-4 months (58). Treatment should be initiated with an ACE inhibitor, angiotensin receptor blocker (ARB), long acting calcium channel blocker or a thiazide diuretic. Studies completed in children do not find significant differences in the effectiveness between these different agents and show few adverse effects $(65,66)$. When hypertension is in combination with T2DM, ACE inhibitor or ARB are recommended as firstline therapy $(8,58,67)$. Combination therapy may be required if HTN does not normalize on single agent therapy (58). In children requiring pharmacologic treatment, lifestyle changes should be continued, also in order to improve antihypertensive medications efficacy (58).

\section{DYSLIPIDEMIA}

The association of obesity and hyperlipidemia is predictive of fatal and non-fatal cardiovascular events in adult life (68). The role of dietary fat intake in increasing cardiovascular risk is still debated $(69,70)$. A review of De Souza et al. reports no association between saturated fat intake and cardiovascular disease (69). In addition available evidence from randomized controlled trials shows that saturated fatty acids replacement with polyunsaturated fatty acids reduces serum cholesterol levels but not results in a lower risk of death from coronary heart disease (70). However, recent evidences support the importance of the type of fats consumed rather than total fat intake in influencing cardiovascular health and recommend to avoid industrially produced trans-fats (71).

The type of dyslipidemia associated with Mets is usually treated with lifestyle interventions only, but medications should be initiated when appropriate. The authors of the Expert Panel Guidelines for Cardiovascular Health and Risk Reduction published in 2011 provide the evidence based guidance for dietary management of dyslipidemia in children and adolescents (CHILD 1 and CHILD 2 approach) (8). A reduction of total fat between 25 and $30 \%$ of daily calories and of saturated fat $<10 \%$ 
calories and a cholesterol intake $<300 \mathrm{mg}$ /day has been shown to safely and effectively reduce total cholesterol and LDL cholesterol (8). When indicated, more stringent diet restrictions have been shown to be safe and modestly effective (8).

In children with obesity and elevated triglyceride level, reduction of simple carbohydrates intake is also effective. The use of plant sterols or stanol esters is usually reserved for children with primary elevation of LDL cholesterol (8).

For children who will unlikely achieve lipid targets with behavioral modifications alone, pharmacologic treatment should be evaluated and it should always be proposed considering the context of complete CVR profile of the patient (8). To define the cut-off points at which the pharmacologic therapy should be considered the American Academy of Pediatrics refers to 1992 National Cholesterol Education Program Guidelines (72). Elevated triglycerides and low HDL cholesterol with relatively normal LDL cholesterol represent the specific features of dyslipidemia in MetS $(5,13)$. Pharmacological treatment is rarely necessary for children with elevated triglyceride levels that have a good response to weight loss and lifestyle changes. Increased fish intake or fish-oil supplementation may be considered (8). Initiation of medication therapy should be proposed on the basis of a specific step-intervention well described in the AAP Expert Panel Guidelines (8). In particular, the use of statin is indicated when a moderate hypertriglyceridemia (200-499 mg/dl-2.26$5.64 \mathrm{mmol} / \mathrm{l}$ ) is associated with non-HDL cholesterol level above $145 \mathrm{mg} / \mathrm{dl}-3.76 \mathrm{mmol} / \mathrm{l}(8,73)$. At present, FDA does not approve in children the use of other triglycerides level-lowering medications, such as fibrate and nicotinic acid (73).

\section{GLUCOSE IMPAIRMENTS AND TYPE 2 DIABETES MELLITUS}

Treatment of insulin resistance (IR) involves lifestyle modification only. The use of metformin to treat children and adolescents with IR but not abnormal glucose concentrations is uncommon. Although some beneficial effects of metformin on $\mathrm{BMI}$ reduction have been demonstrated, there is no clear evidence for long-term benefits (74-76). In obese adolescents impaired fasting glucose or impaired glucose tolerance are often transient and about $60 \%$ of them revert to normal glucose tolerance within 2 years as the IR of puberty is reduced (77). Less than $2 \%$ of European adolescents with glucose abnormalities develop type 2 diabetes mellitus (T2DM) in the next 5 years $(78,79)$. Therefore, there is currently no evidence base for the use of metformin or other medications for the pharmacological treatment of IR $(67,80)$.

Lifestyle intervention, including dietary and exercise changes, is also the core of treatment of T2DM. Healthy behavioral changes are essential for success also when pharmacological treatment is indicated and should be periodically checked. Initial treatment of youth with T2DM should include metformin and/or insulin alone or in combination, considering the symptoms, the severity of hyperglycemia and the presence or absence of ketosis/ketoacidosis (67). The goal of pharmacologic treatment is to obtain an $\mathrm{HbA} 1 \mathrm{c}<7.0 \%$ (67).
When $\mathrm{HbA} 1 \mathrm{c}$ is $<8.5 \%$ (which corresponds to an estimated average glucose of $200 \mathrm{mg} / \mathrm{dl}$ ) and the patient is asymptomatic and metabolically stable, treatment should be started with metformin with a target of HbAlc $<7 \%$ within 4 months $(67,74)$. Metformin acts reducing hepatic gluconeogenesis and stimulating peripheral glucose uptake (80). Gastrointestinal symptoms (transient abdominal pain, diarrhea or nausea) are the most common side effects reported for metformin use (81). They generally resolve or ameliorate with time or with dose titration and they may be attenuated using extended release formulations (67). The risk of lactic acidosis is extremely low. Addition and titration of basal insulin and, if necessary, of prandial insulin, is recommended when patients fails to reach HbAlc target within 4 months of metformin monotherapy or if contraindications or intolerable side effects of metformin develop $(67,74)$.

When ketosis and/or ketoacidosis are present, intravenous or subcutaneous insulin treatment is recommended $(67,74)$. Once corrected the acute metabolic abnormality, a therapy with intermediate-acting or basal insulin once daily is usually effective. Metformin can also be started along with insulin therapy, also in order to achieve, within 4-6 weeks, effective metformin monotherapy (67).

Blood glucose self-monitoring should be performed regularly during therapy, individualizing the frequency and considering the available resources. Continuous glucose monitoring benefits are still not clearly examined in youth onset T2DM (67).

\section{NAFLD}

Non-alcoholic fatty liver disease (NAFLD) represents the hepatic manifestation of MetS. The goal of treatment of pediatric NAFD is to stop liver injury and reverse the progress form steatosis to steatohepatitis, cirrhosis and its complications (82). The mainstay of treatment for NAFLD remains lifestyle modifications and weight loss. Probiotics and $\omega-3$ fatty acids may ameliorate disease progression (82). Two different double-blind randomized trials demonstrate the favorable effects of probiotics (Lactobacillus GG and VLS\#3) in obese children with steatosis $(83,84)$. However, long-term follow-up studies are necessary to confirm these results. In NAFLD experimental models the use of $\omega$ 3 fatty acids showed benefits in reducing liver steatosis and ameliorating insulin sensitivity and markers of inflammation (85), but clinical trials in humans are still contradictory (86). Although Vitamin $\mathrm{E}$ does not appear to be effective in improving liver histology and reducing aminotransferase levels (87), it is able to improve hepatocellular ballooning in about $40 \%$ of patients with NASH or borderline NASH (88), so it may be considered as a NASH-specific therapy in children (82).

\section{CONCLUSIONS}

Although there is still a lack of consensus on how to define MetS and its components in pediatric population, early identification and treatment of obese children and 
adolescents with multiple metabolic derangements allows to concentrate resources, particularly for children at higher risk, and to target focused intervention aimed to reduce the risk of cardiometabolic disease. Although sometimes the diagnosis is delayed because MetS, as obesity, is underperceived by families, general pediatricians and other pediatric sub specialists, early identification, and management are crucial and may help to attenuate the disease process. An expert multidisciplinary team, which includes pediatrician, mental health practitioner, dietician, nurses, and other referral specialists for the single complications is pivotal, both at the level of prevention and therapy, also in order to offer individualized treatment $(8,22,67,89)$. The economic sustainability of the multidisciplinary team is a challenge for the health system. A policy that involves more investments on this topic would be crucial $(90,91)$.

\section{REFERENCES}

1. Steinberger J, Daniels SR, Eckel RH, Hayman L, Lustig RH, McCrindle $\mathrm{B}$, et al. American heart association atherosclerosis, hypertension, and obesity in the young committee of the council on cardiovascular disease in the young; council on cardiovascular nursing; and council on nutrition, physical activity, and metabolism. Progress and challenges in metabolic syndrome in children and adolescents: a scientific statement from the American heart association atherosclerosis, hypertension, and obesity in the young committee of the council on cardiovascular disease in the young; council on cardiovascular nursing; and council on nutrition, physical activity, and metabolism. Circulation. (2009) 119:62847. doi: 10.1161/CIRCULATIONAHA.108.191394

2. Zimmet P, Alberti KG, Kaufman F, Tajima N, Silink M, Arslanian S, et al. IDF Consensus Group. The metabolic syndrome in children and adolescents - an IDF consensus report. Pediatr Diabetes. (2007) 8:299306. doi: 10.1111/j.1399-5448.2007.00271.x

3. Ford ES, Li C. Defining the metabolic syndrome in children and adolescents: will the real definition please stand up? J Pediatr. (2008) 152:1604. doi: 10.1016/j.jpeds.2007.07.056

4. Weiss R, Bremer AA, Lustig RH. What is metabolic syndrome, and why are children getting it? Ann N Y Acad Sci. (2013) 1281:12340. doi: 10.1111/nyas. 12030

5. Magge SN, Goodman E, Armstrong SC, Committee on Nutrition, Section on Endocrinology, Section on Obesity. The metabolic syndrome in children and adolescents: shifting the focus to cardiometabolic risk factor clustering. Pediatrics. (2017) 140:e20171603. doi: 10.1542/peds.2017-1603

6. Berenson GS, Srinivasan SR, Bao W, Newman WP III, Tracy RE, Wattigney WA. Association between multiple cardiovascular risk factors and atherosclerosis in children and young adults. The Bogalusa Heart Study. $N$ Engl J Med. (1998) 338:1650-56. doi: 10.1056/NEJM199806043382302

7. Barlow SE, Expert Committee. Expert committee recommendations regarding the prevention, assessment, and treatment of child and adolescent overweight and obesity: summary report. Pediatrics. (2007) 120:S16492. doi: 10.1542/peds.2007-2329C

8. Expert Panel on Integrated Guidelines for Cardiovascular Health and Risk Reduction in Children and Adolescents, National Heart, Lung, and Blood Institute. Expert panel on integrated guidelines for cardiovascular health and risk reduction in children and adolescents: summary report. Pediatrics. (2011) 128:S213-56. doi: 10.1542/peds.2009-2107C

9. Morrison JA, Friedman LA, Wang P, Glueck CJ. Metabolic syndrome in childhood predicts adult metabolic syndrome and type 2 diabetes mellitus 25 to 30 years later. J Pediatr. (2008) 152:201-6. doi: 10.1016/j.jpeds.2007.09.010

10. Steinberger J, Daniels SR, American Heart Association Atherosclerosis, Hypertension, and Obesity in the Young Committee (Council on Cardiovascular Disease in the Young), American Heart Association

\section{AUTHOR CONTRIBUTIONS}

$\mathrm{EF}$ and $\mathrm{CM}$ gave a substantial contribution to the conception of the work, the acquisition, analysis, or interpretation of data for the work, provide approval for publication of the content, and agree to be accountable for all aspects of the work in ensuring that questions related to the accuracy or integrity of any part of the work are appropriately investigated and resolved. EF wrote the manuscript and CM revised it critically for important intellectual content.

\section{FUNDING}

This work was supported by the FURMAFF, Department of Surgical Sciences, Dentistry, Paediatrics, and Gynaecology, University of Verona.

Diabetes Committee (Council on Nutrition, Physical Activity, and Metabolism). Obesity, insulin resistance, diabetes, and cardiovascular risk in children: an American Heart Association scientific statement from the Atherosclerosis, Hypertension, and Obesity in the Young Committee (Council on Cardiovascular Disease in the Young) and the Diabetes Committee (Council on Nutrition, Physical Activity, and Metabolism). Circulation. (2003) 107:1448-53. doi: 10.1161/01.CIR.0000060923. 07573.F2

11. Ogden CL, Carroll MD, Lawman HG, Fryar CD, Kruszon-Moran D, Kit BK, et al. Trends in obesity prevalence among children and adolescents in the United States, 1988-1994 Through 2013-2014. JAMA. (2016) 315:22929. doi: 10.1001/jama.2016.6361

12. Flegal KM, Carroll MD, Kit BK, Ogden CL. Prevalence of obesity and trends in the distribution of body mass index among US adults, 1999-2010. JAMA. (2012) 307:491-7. doi: 10.1001/jama.2012.39

13. Wittcopp C, Conroy R. Metabolic syndrome in childrenand adolescents. Pediatr Rev. (2016) 37:193-202. doi: 10.1542/pir.2014-0095

14. Whitlock EP, O'Connor EA, Williams SB, Beil TL, Lutz KW. Effectiveness of primary care interventions for weight management in children and adolescents: an updated, targeted systematic review for the USPSTF. Pediatrics. (2010) 125:e396-418. doi: 10.1542/peds.2009-1955

15. Ho M, Garnett SP, Baur L, Burrows T, Stewart L, Neve M, et al. Effectiveness of lifestyle interventions in child obesity: systematic review with meta-analysis. Pediatrics. (2012) 130: e1647-71. doi: 10.1542/peds.2012-1176

16. Rajjo T, Mohammed K, Alsawas M, Ahmed AT, Farah W, Asi N, et al. Treatment of pediatric obesity: an umbrella systematic review. J Clin Endocrinol Metab. (2017) 102:763-75. doi: 10.1210/jc.2016-2574

17. Meyer AA, Kundt G, Lenschow U, Schuff-Werner P, Kienast W. Improvement of early vascular changes and cardiovascular risk factors in obese children after a six-month exercise program. J Am Coll Cardiol. (2006) 48:186570. doi: 10.1016/j.jacc.2006.07.035

18. Kamath CC, Vickers KS, Ehrlich A, McGovern L, Johnson J, Singhal V, et al. Clinical review: behavioral interventions to prevent childhood obesity: a systematic review and metaanalyses of randomized trials. J Clin Endocrinol Metab. (2008) 93:4606-15. doi: 10.1210/jc.2006-2411

19. Bremer AA, Mietus-Snyder M, Lustig RH. Toward a unifying hypothesis of metabolic syndrome. Pediatrics. (2012) 129:55770. doi: 10.1542/peds.2011-2912

20. Styne DM, Arslanian SA, Connor EL, Farooqi IS, Murad MH, Silverstein JH, et al. Pediatric obesity-assessment, treatment, and prevention: an endocrine society clinical practice guideline. J Clin Endocrinol Metab. (2017) 102:70957. doi: 10.1210/jc.2017-00561

21. Gow ML, Ho M, Burrows TL, Baur LA, Stewart L, Hutchesson MJ, et al. Impact of dietary macronutrient distribution on BMI and cardiometabolic outcomes in overweight and obese children and adolescents: a systematic review. Nutr Rev. (2014) 72:453-70. doi: 10.1111/nure.12111 
22. Valerio G, Maffeis C, Saggese G, Ambruzzi MA, Balsamo A, Bellone S, et al. Diagnosis, treatment and prevention of pediatric obesity: consensus position statement of the Italian Society for Pediatric Endocrinology and Diabetology and the Italian Society of Pediatrics. Ital J Pediatr. (2018) 44:88. doi: 10.1186/s13052-018-0525-6

23. French SA, Sherwood NE, JaKa MM, Haapala JL, Ebbeling CB, Ludwig DS. Physical changes in the home environment to reduce television viewing and sugar-sweetened beverage consumption among 5- to 12 year-old children: a randomized pilot study. Pediatr Obes. (2016) 11:e125. doi: 10.1111/ijpo.12067

24. James J, Thomas P, Cavan D, Kerr D. Preventing childhood obesity by reducing consumption of carbonated drinks: cluster randomised controlled trial. BMJ. (2004) 328:1237. doi: 10.1136/bmj.38077.458438.EE

25. Reinehr T, Widhalm K, l'Allemand D, Wiegand S, Wabitsch M, Holl RW, et al. Two-year follow-up in 21,784 overweight children and adolescents with lifestyle intervention. Obesity. (2009) 17:1196-9. doi: 10.1038/oby.2009.17

26. Maffeis C, Castellani M. Physical activity: an effective way to control weight in children? Nutr Metab Cardiovasc Dis. (2007) 17:394-408. doi: 10.1016/j.numecd.2006.08.006

27. Maffeis C, Zaffanello M, Pellegrino M, Banzato C, Bogoni G, Viviani E, et al. Nutrient oxidation during moderately intense exercise in obese prepubertal boys. J Clin Endocrinol Metab. (2005) 90:231-6. doi: 10.1210/jc.2004-0715

28. Shultz SP, Browning RC, Schutz Y, Maffeis C, Hills AP. Childhood obesity and walking: guidelines and challenges. Int J Pediatr Obes. (2011) 6:33241. doi: 10.3109/17477166.2011.590202

29. Lee IM, Shiroma EJ, Lobelo F, Puska P, Blair SN, Katzmarzyk PT, et al. Effect of physical inactivity on major non-communicable diseases worldwide: an analysis of burden of disease and life expectancy. Lancet. (2012) 380:21929. doi: 10.1016/S0140-6736(12)61031-9

30. Stabelini Neto A, de Campos W, Dos Santos GC, Mazzardo Junior O. Metabolic syndrome risk score and time expended in moderate to vigorous physical activity in adolescents. BMC Pediatr. (2014) 14:42. doi: 10.1186/1471-2431-14-42

31. Schmitz KH, Jacobs DR Jr, Hong CP, Steinberger J, Moran A, Sinaiko AR. Association of physical activity with insulin sensitivity in children. Int J Obes Relat Metab Disord. (2002) 26:1310-16. doi: 10.1038/sj.ijo.0802137

32. Moghetti P, Bacchi E, Brangani C, Donà S, Negri C. Metabolic effects of exercise. Front Horm Res. (2016) 47:44-57. doi: 10.1159/000445156

33. Escalante Y, Saavedra JM, García-Hermoso A, Domínguez AM. Improvement of the lipid profile with exercise in obese children: a systematic review. Prev Med. (2012) 54:293-301. doi: 10.1016/j.ypmed.2012.02.006

34. Farpour-Lambert NJ, Aggoun Y, Marchand LM, Martin XE, Herrmann FR, Beghetti M. Physical activity reduces systemic blood pressure and improves early markers of atherosclerosis in pre-pubertal obese children. J Am Coll Cardiol. (2009) 54:2396-406. doi: 10.1016/j.jacc.2009.08.030

35. McGovern L, Johnson JN, Paulo R, Hettinger A, Singhal V, Kamath C, et al. Clinical review: treatment of pediatric obesity: a systematic review and meta-analysis of randomized trials. J Clin Endocrinol Metab. (2008) 93:46005. doi: 10.1210/jc.2006-2409

36. Stoner L, Rowlands D, Morrison A, Credeur D, Hamlin M, Gaffney K, et al. Efficacy of exercise intervention for weight loss in overweight and obese adolescents: meta-analysis and implications. Sports Med. (2016) 46:173751. doi: 10.1007/s40279-016-0537-6

37. Rubin DA, Hackney AC. Inflammatory cytokines and metabolic risk factors during growth and maturation: influence of physical activity. Med Sport Sci. (2010) 55:43-55. doi: 10.1159/000321971

38. Schwartz C, King NA, Perreira B, Blundell JE, Thivel D. A systematic review and meta-analysis of energy and macronutrient intake responses to physical activity interventions in children and adolescents with obesity. Pediatr Obes. (2017) 12:179-94. doi: 10.1111/ijpo.12124

39. Piercy KL, Troiano RP, Ballard RM, Carlson SA, Fulton JE, Galuska DA, et al. The physical activity guidelines for Americans. JAMA. (2018) 320:20208. doi: 10.1001/jama.2018.14854

40. Epstein LH, Roemmich JN, Robinson JL, Paluch RA, Winiewicz DD, Fuerch $\mathrm{JH}$, et al. A randomized trial of the effects of reducing television viewing and computer use on body mass index in young children. Arch Pediatr Adolesc Med. (2008) 162:239-45. doi: 10.1001/archpediatrics.2007.45
41. Weng SF, Redsell SA, Swift JA, Yang M, Glazebrook CP. Systematic review and meta-analyses of risk factors for childhood overweight identifiable during infancy. Arch Dis Child. (2012) 97:1019-26. doi: 10.1136/archdischild-2012-302263

42. National Sleep Foundation. National Sleep Foundation Recommends New Sleep Durations (2016). Available online at: https://sleepfoundation.org/pressrelease/national-sleep-foundation-recommends-new-sleep-times (accessed October 4, 2019).

43. Czernichow S, Lee CM, Barzi F, Greenfield JR, Baur LA, Chalmers J, et al. Efficacy of weight loss drugs on obesity and cardiovascular risk factors in obese adolescents: a meta-analysis of randomized controlled trials. Obes Rev. (2010) 11:150-8. doi: 10.1111/j.1467-789X.2009.00620.x

44. Yanovski SZ, Yanovski JA. Longterm drug treatment for obesity: a systematic and clinical review. JAMA. (2014) 311:74-86. doi: 10.1001/jama.2013.281361

45. Boland CL, Harris JB, Harris KB. Pharmacological management of obesity in pediatric patients. Ann Pharmacother. (2015) 49:220-32. doi: 10.1177/1060028014557859

46. McDuffie JR, Calis KA, Uwaifo GI, Sebring NG, Fallon EM, Hubbard VS, et al. Three-month tolerability of orlistat in adolescents with obesity-related comorbid conditions. Obes Res. (2002) 10:642-50. doi: 10.1038/oby.2002.87

47. McDuffie JR, Calis KA, Uwaifo GI, Sebring NG, Fallon EM, Frazer TE, et al. Efficacy of orlistat as an adjunct to behavioral treatment in overweight African American and Caucasian adolescents with obesityrelatedco-morbid conditions. J Pediatr Endocrinol Metab. (2004) 17:30719. doi: 10.1515/JPEM.2004.17.3.307

48. Khera R, Murad MH, Chandar AK, Dulai PS, Wang Z, Prokop LJ, et al. Association of pharmacological treatments for obesity with weight loss and adverse events: a systematic review and meta-analysis. JAMA. (2016) 315:2424-34. doi: 10.1001/jama.2016.7602

49. Kelly AS, Rudser KD, Nathan BM, Fox CK, Metzig AM, Coombes BJ, et al. The effect of glucagon-like peptide-1 receptor agonist therapy on body mass index in adolescents with severe obesity: a randomized, placebo-controlled, clinical trial. JAMA Pediatr. (2013) 167:355-60. doi: 10.1001/jamapediatrics.2013.1045

50. Mead E, Atkinson G, Richter B, Metzendorf MI, Baur L, Finer $\mathrm{N}$, et al. Drug interventions for the treatment of obesity in children and adolescents. Cochrane Database Syst Rev. (2016) 11:CD012436. doi: 10.1002/14651858.CD012436

51. Inge TH, Courcoulas AP, Jenkins TM, Michalsky MP, Helmrath MA, Brandt ML, et al. Teen-LABS Consortium. Weight loss and health status 3 years after bariatric surgery in adolescents. N Engl J Med. (2016) 374:11323. doi: 10.1056/NEJMoa1506699

52. Black JA, White B, Viner RM, Simmons RK. Bariatric surgery for obese children and adolescents: a systematic review and meta-analysis. Obes Rev. (2013) 14:634-44. doi: 10.1111/obr.12037

53. Bray GA, Heisel WE, Afshin A, Jensen MD, Dietz WH, Long M, et al. The science of obesity management: an endocrine society scientific statement. Endocr Rev. (2018) 39:79-132. doi: 10.1210/er.2017-00253

54. Spear BA, Barlow SE, Ervin C, Ludwig DS, Saelens BE, Schetzina KE, et al. Recommendations for treatment of child and adolescent overweight and obesity. Pediatrics. (2007) 120:S254-88. doi: 10.1542/peds.2007-2329F

55. Inge $\mathrm{TH}$, Courcoulas AP, Jenkins TM, Michalsky MP, Brandt ML, Xanthakos SA, et al. Five-year outcomes of gastric bypass in adolescents as compared with adults. N Engl J Med. (2019) 380:2136-45. doi: 10.1056/ NEJMoa1813909

56. Inge TH, Jenkins TM, Xanthakos SA, Dixon JB, Daniels SR, Zeller MH, et al. Long-term outcomes of bariatric surgery in adolescents with severe obesity: a prospective follow-up analysis. Lancet Diabetes Endocrinol. (2017) 5:165-73. doi: 10.1016/S2213-8587(16)30315-1

57. Pedroso FE, Angriman F, Endo A, Dasenbrock H, Storino A, Castillo $\mathrm{R}$, et al. Weight loss after bariatric surgery in obese adolescents: a systematic review and meta-analysis. Surg Obes Relat Dis. (2018) 14:41322. doi: 10.1016/j.soard.2017.10.003

58. Flynn JT, Kaelber DC, Baker-Smith CM, Blowey D, Carroll AE, Daniels $\mathrm{SR}$, et al. Clinical practice guideline for screening and management of high blood pressure in children and adolescents. Pediatrics. (2017) 140:e20171904. doi: 10.1542/peds.2017-3035 
59. Adler AJ, Taylor F, Martin N, Gottlieb S, Taylor RS, Ebrahim S. Reduced dietary salt for the prevention of cardiovascular disease. Cochrane Database Syst Rev. (2014) 18:CD009217. doi: 10.1002/14651858.CD009217.pub3

60. Yang Q, Zhang Z, Kuklina EV, Fang J, Ayala C, Hong Y, et al. Sodium intake and blood pressure among US children and adolescents. Pediatrics. (2012) 130:611-19. doi: 10.1542/peds.2011-3870

61. Moreno-Luna R, Muñoz-Hernandez R, Miranda ML, Costa AF, JimenezJimenez L, Vallejo-Vaz AJ, et al. Olive oil polyphenols decrease blood pressure and improve endothelial function in young women with mild hypertension. Am J Hypertens. (2012) 25:1299-304. doi: 10.1038/ajh.2012.128

62. Damasceno MM, de Araújo MF, de Freitas RW, de Almeida PC, Zanetti ML. The association between blood pressure in adolescents and the consumption of fruits, vegetables and fruit juice-an exploratory study. J Clin Nurs. (2011) 20:1553-60. doi: 10.1111/j.1365-2702.2010.03608.x

63. Moore LL, Bradlee ML, Singer MR, Qureshi MM, Buendia JR, Daniels SR. Dietary approaches to stop hypertension (DASH) eating pattern and risk of elevated blood pressure in adolescent girls. Br J Nutr. (2012) 108:167885. doi: 10.1017/S000711451100715X

64. Torrance B, McGuire KA, Lewanczuk R, McGavock J. Overweight, physical activity and high blood pressure in children: a review of the literature. Vasc Health Risk Manag. (2007) 3:139-49.

65. Herder SD, Weber E, Winkemann A, Herder C, Morck H. Efficacy and safety of angiotensin II receptor type 1 antagonists in children and adolescents. Pediatr Nephrol. (2010) 25:801-11. doi: 10.1007/s00467-009-1346-Z

66. Schaefer F, Litwin M, Zachwieja J, Zurowska A, Turi S, Grosso A, et al. Efficacy and safety of valsartan compared to enalapril in hypertensive children: a 12week, randomized, double-blind, parallel-group study. J Hypertens. (2011) 29:2484-90. doi: 10.1097/HJH.0b013e32834c625c

67. Zeitler P, Arslanian S, Fu J, Pinhas-Hamiel O, Reinehr T, Tandon $\mathrm{N}$, et al. ISPAD clinical practice consensus guidelines 2018: type 2 diabetes mellitus in youth. Pediatr Diabetes. (2018) 19:28-46. doi: 10.1111/ pedi.12719

68. Morrison JA, Glueck CJ, Woo JG, Wang P. Risk factors for cardiovascular disease and type 2 diabetes retained from childhood to adulthood predict adult outcomes: the Princeton LRC follow-up study. Int J Pediatr Endocrinol. (2012) 2012:6. doi: 10.1186/1687-9856-2012-6

69. De Souza RJ, Mente A, Maroleanu A, Cozma AI, Ha V, Kishibe $\mathrm{T}$, et al. Intake of saturated and trans unsaturated fatty acids and risk of all cause mortality, cardiovascular disease, and type 2 diabetes: systematic review and meta-analysis of observational studies. BMJ. (2015) 351:h3978. doi: 10.1136/bmj.h3978

70. Ramsden CE, Zamora D, Majchrzak-Hong S, Faurot KR, Broste SK, Frantz $\mathrm{RP}$, et al. Re-evaluation of the traditional diet-heart hypothesis: analysis of recovered data from Minnesota Coronary Experiment (1968-73). BMJ. (2016) 353:i1246. doi: 10.1136/bmj.i1246

71. Forouhi NG, Krauss RM, Taubes G, Willett W. Dietary fat and cardiometabolic health: evidence, controversies, and consensus for guidance. BMJ. (2018) 361:k2139. doi: 10.1136/bmj.k2139

72. NCEP Expert Panel of Blood Cholesterol Levels in Children and Adolescents. National Cholesterol Education Program (NCEP): highlights of the report of the expert panel on blood cholesterol levels in children and adolescents. Pediatrics. (1992) 89:495-501.

73. Valaiyapathi B, Sunil B, Ashraf AP. Approach to Hypertriglyceridemia in the pediatric population. Pediatr Rev. (2017) 38:42434. doi: 10.1542/pir.2016-0138

74. American Diabetes Association. Children and adolescents: standards of medical care in diabetes-2018. Diabetes Care. (2018) 41:S126-36. doi: 10.2337/dc18-S012

75. McDonagh MS, Selph S, Ozpinar A, Foley C. Systematic review of the benefits and risks of metformin in treating obesity in children aged 18 years and younger. JAMA Pediatr. (2014) 168:178-84. doi: 10.1001/jamapediatrics.2013.4200

76. Park MH, Kinra S, Ward KJ, White B, Viner RM. Metformin for obesity in children and adolescents: a systematic review. Diabetes Care. (2009) 32:17435. doi: $10.2337 / \mathrm{dc} 09-0258$
77. Reinehr T, Wolters B, Knop C, Lass N, Holl RW. Strong effect of pubertal status on metabolic health in obese children: a longitudinal study. J Clin Endocrinol Metab. (2015) 100:301-8. doi: 10.1210/jc.2014-2674

78. Kleber M, deSousa G, Papcke S, Wabitsch M, Reinehr T. Impaired glucose tolerance in obese white children and adolescents: three to five year followup in untreated patients. Exp Clin Endocrinol Diabetes. (2011) 119:1726. doi: 10.1055/s-0030-1263150

79. Kleber M, Lass N, Papcke S, Wabitsch M, Reinehr T. One-year follow-up of untreated obese white children and adolescents with impaired glucose tolerance: high conversion rate to normal glucose tolerance1. Diabet Med. (2010) 27:516-21. doi: 10.1111/j.1464-5491.2010.02991.x

80. Giannarelli R, Aragona M, Coppelli A, Del Prato S. Reducing insulin resistance with metformin: the evidence today. Diabetes Metab. (2003) 29:6S28-35 doi: 10.1016/S1262-3636(03)72785-2

81. McCreight LJ, Bailey CJ, Pearson ER. Metformin and the gastrointestinal tract. Diabetologia. (2016) 59:426-35. doi: 10.1007/s00125-015-3844-9

82. Nobili V, Alkhouri N, Alisi A, Della Corte C, Fitzpatrick E, Raponi M, et al. Nonalcoholic fatty liver disease: a challenge for pediatricians. JAMA Pediatr. (2015) 169:170-6. doi: 10.1001/jamapediatrics.2014.2702

83. Vajro P, Mandato C, Licenziati MR, Franzese A, Vitale DF, Lenta $\mathrm{S}$, et al. Effects of Lactobacillus rhamnosus strain GG in pediatric obesity-related liver disease. J Pediatr Gastroenterol Nutr. (2011) 52:7403. doi: 10.1097/MPG.0b013e31821f9b85

84. Alisi A, Bedogni G, Baviera G, Giorgio V, Porro E, Paris C, et al. Randomised clinical trial: the beneficial effects of VSL\#3 in obese children with non-alcoholic steatohepatitis. Aliment Pharmacol Ther. (2014) 39:127685. doi: 10.1111/apt.12758

85. Masterton GS, Plevris JN, Hayes PC. Review article: omega-3 fatty acidsa promising novel therapy for non-alcoholic fatty liver disease. Aliment Pharmacol Ther. (2010) 31:679-92. doi: 10.1111/j.1365-2036.2010.04230.x

86. Janczyk W, Lebensztejn D, Wierzbicka-Rucinska A, Mazur A, NeuhoffMurawska J, Matusik P, et al. Omega-3 Fatty acids therapy in children with nonalcoholic Fatty liver disease: a randomized controlled trial. J Pediatr. (2015) 166:1358-63. doi: 10.1016/j.jpeds.2015.01.056

87. Nobili V, Manco M, Devito R, Ciampalini P, Piemonte F, Marcellini M. Effect of vitamin $\mathrm{E}$ on aminotransferase levels and insulin resistance in children with non-alcoholic fatty liver disease. Aliment Pharmacol Ther. (2006) 24:155361. doi: 10.1111/j.1365-2036.2006.03161.x

88. Lavine JE, Schwimmer JB, Van Natta ML, Molleston JP, Murray KF, Rosenthal $\mathrm{P}$, et al. Nonalcoholic steatohepatitis clinical research network. Effect of vitamin $\mathrm{E}$ or metformin for treatment of nonalcoholic fatty liver disease in children and adolescents: the TONIC randomized controlled trial. JAMA. (2011) 305:1659-68. doi: 10.1001/jama.2011.520

89. Bischoff SC, Boirie Y, Cederholm T, Chourdakis M, Cuerda C, Delzenne NM, et al. Towards a multidisciplinary approach to understand and manage obesity and related diseases. Clin Nutr. (2017) 36:917-38. doi: 10.1016/j.clnu.2016.11.007

90. Lobstein T, Jackson-Leach R, Moodie ML, Hall KD, Gortmaker SL, Swinburn BA, et al. Child and adolescent obesity: part of a bigger picture. Lancet. (2015) 385:2510-20. doi: 10.1016/S0140-6736(14)61746-3

91. Zomer E, Leach R, Trimmer C, Lobstein T, Morris S, James WP, et al. Effectiveness and cost-effectiveness of interventions that cause weight loss and reduce the risk of cardiovascular disease. Diabetes Obes Metab. (2017) 19:118-24. doi: 10.1111/dom.12792

Conflict of Interest: The authors declare that the research was conducted in the absence of any commercial or financial relationships that could be construed as a potential conflict of interest.

Copyright (c) 2019 Fornari and Maffeis. This is an open-access article distributed under the terms of the Creative Commons Attribution License (CC BY). The use, distribution or reproduction in other forums is permitted, provided the original author(s) and the copyright owner(s) are credited and that the original publication in this journal is cited, in accordance with accepted academic practice. No use, distribution or reproduction is permitted which does not comply with these terms. 